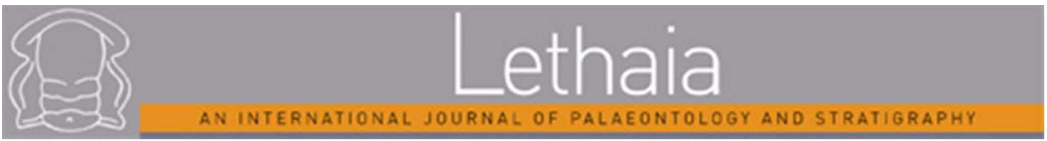

\title{
Lingulate brachiopods and the lower palaeozoic history of the Iapetus Ocean
}

\begin{tabular}{|r|l|}
\hline Journal: & Lethaia \\
\hline Manuscript ID: & Draft \\
\hline Manuscript Type: & Original Article \\
\hline Date Submitted by the Author: & $\mathrm{n} / \mathrm{a}$ \\
\hline Complete List of Authors: & $\begin{array}{l}\text { Winrow, Paul; Imperial College London, Deparment of Earth Science and } \\
\text { Engineering } \\
\text { Sutton, Mark; Imperial College London, Earth Science and Engineering }\end{array}$ \\
\hline Keywords: & Iapetus, palaeobiogeography, lingulate, brachiopod, similarity \\
\hline
\end{tabular}




\section{Lingulate brachiopods and the lower palaeozoic history of the Iapetus Ocean} (Lingulate brachiopods and history of Iapetus Ocean)

Paul Winrow and Mark D Sutton

The history of the Iapetus Ocean in the lower Palaeozoic is well established and faunal distribution has contributed significantly to the development of this knowledge; however, lingulate brachiopods have traditionally been considered to be of little utility in assessing palaeobiogeography. The distribution of lingulate brachiopods across the Iapetus region is analysed using a number of similarity indices and other statistical measures. This analysis shows a clear palaeobiogeographic signal where lingulate faunas are sufficiently diverse, reflecting the history of the Iapetus ocean and the relative separation of Laurentia and Baltica through the Cambrian and Ordovician. Lingulate faunas on Avalonia are, however, low in diversity and show relatively high endemism; this renders them of little use in assessing the separation of Avalonia from other areas. Evidence of earlier increases in faunal similarity in lingulate faunas between continents, compared to other fossil groups, provides confirmatory evidence that Palaeozoic lingulates had long-lived planktotrophic larvae. Keywords: Iapetus, palaeobiogeography, lingulate, brachiopod, similarity

PaulWinrow(p.winrow07@imperial.ac.uk)and MarkD Sutton(m.sutton@imperial.ac.uk),Department of Earth Science and Engineering, Imperial College London, South Kensington Campus, London, SW7 $2 A Z$ 
Ever since Wilson (1966) demonstrated the existence of a "proto Atlantic" Iapetus Ocean, there has been much interest in the Palaeozoic development of the region, particularly in the history of the northern (Laurentian) and southern (Avalonian) British Isles, culminating in a recent popular science depiction of the closure of the Iapetus Ocean (Clarkson \& Upton 2010). The ocean opened in the Vendian to Early Cambrian and, although the details of the timing of rifting and palaeogeographic configuration of the continents are not clear (Pisarevsky et al. 2008), the ocean was formed as Laurentia rifted away from Gondwana and drifted northwards towards the equator (Torsvik et al. 1996; Carwood et al. 2001) and the Tornquist Sea opened as Baltica rifted away from the Gondwanan margin.

The Cambrian was a period of continental dispersion and the Iapetus continued to widen, reaching its maximum width in the latest Cambrian to early Ordovician with a distance of 5,000km separating Avalonian and Laurentian Britain (Cocks \& Torsvik 2002) and the Tornquist Sea continued to widen as Baltica drifted northward. Avalonia rifted from the Gondwanan margin opening up the Rheic Ocean, probably during Arenig time according to Cocks and Fortey (2009) although Landing (2005) contends that Avalonia had been an independent terrane since the Neoproterozoic, drifting rapidly northwards and reaching a similar latitude to Baltica by the Caradoc, lying approximately $1,000 \mathrm{~km}$ to the west (Cocks $\&$ Torsvik 2002).

By the middle Ordovician the Iapetus had begun to narrow, to $3,300 \mathrm{~km}$ by end Llandeilo (Torsvik \& Trench 1991 and Torsvik et al. 1993) and by the Caradoc the separation of Avalonian and Laurentian Britain had reduced to $2,000 \mathrm{~km}$ (Cocks \& Torsvik 2002). There is strong palaeomagnetic and faunal evidence for the existence of Island Arcs across the Iapetus Ocean in the early to mid Ordovician due to subduction of the northern (Laurentian) and southern (Avalonian) margins as well as a mid latitude Arc system (Mac Niocaill et al. 1997). Throughout middle to late Ordovician times the Tornquist Sea continued to narrow as Avalonia and Baltica converged, finally 'soft docking' around the Ordovician/Silurian boundary (Mac Niocaill et al. 1997; Cocks and Torsvik 2002; Torsvik \& Rehnstrom 
2003) when the Iapetus Ocean had reduced to around 1,300km wide and the Rheic Ocean had reached its maximum width of around 5,000km. The Iapetus continued to narrow until, in the mid Silurian, the Avalonia/Baltica continent collided with Laurentia to create Laurussia as the ocean disappeared during the Caledonide orogeny.

The chronostratigraphic terminology used herein is that used in the Treatise on Invertebrate Palaeontology (Kaesler 1997; 2000 and Selden 2007) on which the data analysis is based. Ordovician chronostratigraphic nomenclature has been updated since publication of the Treatise; Figure 1 summarises the stage and series names used herein against the current global terminology.

\section{[insert Figure 1 here]}

\section{Faunal evidence for the history of the Iapetus Ocean}

For several decades the distribution of fossils has been widely applied to palaeogeographical questions, in particular in the development and closure of the Iapetus Ocean with faunal evidence a significant factor leading Wilson (1966) to identify the "proto Atlantic". Williams (1973) identified five Ordovician brachiopod provinces in the Arenig with high levels of endemism, reducing to two 'realms' by the Caradoc and by the latest Ashgill a single, cosmopolitan fauna existed (the Hirnantia fauna) as the Iapetus closed and Cocks \& McKerrow (1973) demonstrated that Silurian shelf brachiopod faunas were essentially cosmopolitan. Meanwhile, Whittington \& Hughes (1972) demonstrated a similar trend in trilobite provinces, reducing from four in the lower Ordovician to a single late Ordovician worldwide fauna due to continental amalgamation as well as global regression due to the end Ordovician glaciation and association extinctions. McKerrow \& Cocks (1986) noted that faunas on either side of the Iapetus Ocean became increasingly similar through time and calculated the approximate width of the Iapetus through the lower Palaeozoic based on the times at which faunas on either side of the ocean were able to cross it. Additionally Cocks (2000) summarised the faunal evidence for the palaeogeography of the early Ordovician noting that Laurentia and Baltica had largely endemic brachiopod and trilobite faunas at this 
time and also identified the increasing differences between Avalonian and Gondwanan brachiopod faunas which were broadly similar in the Arenig but markedly different by the Llanvirn and Caradoc as demonstrated by the work of Hurst (1979) and Havlicek et al. (1994).

In two seminal papers, Cocks \& Fortey (1982) and Fortey \& Cocks (1992) documented the fossil evidence for the separation of northern and southern Britain, based on mainly articulate brachiopods and trilobites, noting that the significant faunal differences in the Cambrian and lower Ordovician gradually declined in the later Ordovician, reflecting the closure of the Iapetus Ocean. They noted also that early Ordovician faunas in southern Britain (Avalonia) were similar to those in Gondwanan Europe, whilst those in Baltica were different. These authors have built on this early work in a series of papers providing greater detail of faunal distributions and the evidence for palaeogeographical reconstructions including Cocks \& Fortey (1990) outlining the biogeography of Ordovician and Silurian faunas, and the major review of the palaeontological evidence supporting global Ordovician and Silurian reconstructions (Fortey \& Cocks 2003) which provides a detailed summary of the faunal distributions for each continent and the main microcontinents and terranes.

Cocks \& Fortey (2009) discussed the history of Avalonia, focussing mainly on faunal evidence, and noted that faunal evidence for the location of Avalonia in the Cambrian is inconclusive; Lower Cambrian trilobites are typified by Gondwanan faunas with high endemicity (Alvaro et al. 2003) whereas, in the middle Cambrian faunas have some similarity with both Laurentia and Baltica and in the late Cambrian there is some evidence of links to Gondwana (Hughes \& Rushton 1990). Conway Morris \& Rushton (1988) summarised the differences between the faunas of Laurentia, Avalonia and Baltica through the Cambrian as evidence of their separation at this time, focussing on trilobites but with support from other groups, noting also the environmental differences between low latitude, and warmer, Laurentia and the higher latitude, cooler waters of Avalonia and Baltica. In other fossil groups, Williams et al. (2007) outlined the Cambrian palaeogeography of bradoriid arthropods which show evidence of a warm water 
"east" and cooler water "west" realm, similar to the Olenellid and Redlichiid trilobite realms, with many forms being cosmopolitan within those realms, although Topper et al. (2011) provided strong evidence for endemism in the lower Cambrian.

Harper et al. (1996) and Cocks \& Torsvik (2002) provide syntheses of palaeomagnetic and faunal data for early Ordovician Iapetus terranes and global geography for the Ordovician and Silurian respectively whilst Neuman (1984) and Harper et al. (2009) discuss the geology and palaeontology of Ordovician mid latitude, intra-Iapetus islands and the development and migration of the Celtic province faunas. Harper $e t$ al. (1996) identified a series of platform provinces (Laurentia, Baltica and Gondwana) along with a number of assemblages which did not fit these cratonic faunas, particularly the Celtic province at high latitudes and the Toquima-Table Head fauna at lower latitudes. It is likely that the Iapetus was punctuated by numerous islands in the Ordovician (Neuman 1984; Neuman \& Harper 1992), possibly around a mid latitude volcanic arc (Mac Niocaill et al. 1997), upon which largely endemic brachiopod and trilobite faunas developed. Indeed Williams $(1969,1973)$ identified a series of brachiopod provinces at the height of brachiopod provincialism in the early Ordovician which were subsequently refined into the Baltic (Jaanusson 1973), Laurentian (Cocks 2000) and Mediterranean (Havlicek 1976) provinces with a number of intra-Iapetus and marginal faunas also identified (Neuman 1984; Bruton \& Harper 1981). Additionally Tychsen \& Harper (2004) discussed the distribution of orthids in the Ordovician and Silurian, noting five phases in the development of faunal provincialism which, they concluded, reflects the history of the Iapetus. Further, Hansen \& Holmer (2010) note that lower and middle Ordovician faunas from Spitsbergen are similar to those in north America and Greenland at generic level, although there is strong endemism at species level.

Cocks \& Fortey $(1982 ; 1990)$ demonstrated that by the mid Caradoc there was increased faunal exchange between Avalonia and Baltica as they moved closer together whilst Linneman et al. 2012 noted that the Avalonian trilobite faunas were similar to those of north west Gondwana until the Sandbian but from the 
Katian they began to reflect the increased proximity of Baltica (Verniers et al. 2002; Owens \& Servais, 2007). A similar result is found in Chitinozoa from Avalonia which showed Gondwanan affinity until the mid Darriwilian but from the lower Sandbian demonstrated increased similarity to Baltoscandian faunas (Samuelsen \& Verniers 2000; Verniers et al. 2005).

By the mid Silurian the three major Iapetus continents had collided and the benthic assemblages of most groups formed a single, low latitude cosmopolitan fauna, with the exception of ostracodes which, although similar across Baltica and Avalonia were different in Laurentia and NW Gondwana (Cocks \& Fortey 2009) as the ostracodes were apparently unable to cross even the remaining shallow seas until the late Silurian (Berdan 1990). Ziegler et al. (1968) demonstrated that most brachiopod faunas were cosmopolitan by the Llandovery, although lingulate diversity was much reduced by this time. Meanwhile Armstrong \& Owen (2002) analysed euconodonts from the Llanvirn to Llandovery and concluded that many north Atlantic taxa were pelagic and cosmopolitan across the Iapetus area.

Fortey \& Cocks (2003) considered that planktonic taxa, such as graptolites and acritarchs, are more useful in delineating palaeolatitude rather than palaeocontinents on account of their widespread distribution. Fortey \& Mellish (1992) considered whether some fossils are better than others in assessing palaeogeographic models using the early Ordovician Iapetus Ocean as an example, concluding that the relationship to proposed continental separation differs depending on the fossils used. Planktonic fossils (e.g. graptolites, acritarchs) did not denote a separation between Baltica and Gondwana whilst ostracodes, trilobites and to a lesser degree, brachiopods, demonstrate strong compliance with palaeogeographic models; their work on brachiopods was a blend of articulate and inarticulate forms. Meanwhile Lees et al. (2002) used quantitative analysis based mainly on brachiopods and trilobites to estimate distances between continents, noting that in the early Ordovician Avalonia was close to Gondwana but by mid Ordovician times there was increased migration from Laurentia and Baltica of a number of faunal groups including brachiopods, trilobites, molluscs, echinoderms and ostracodes (Cocks \& Fortey 2009); they 
concluded that Avalonia rifted away from Gondwana in the late Cambrian/early Ordovician, probably at the end of the Tremadocian.

A number of papers have been published focussing specifically on the utility of brachiopods in defining the palaeogeographic history of the Iapetus Ocean and surrounding continents, although the majority of these have focussed on articulate brachiopods. As noted by Harper \& Sandy (2001), the geographic distribution of lingulate brachiopods has received little attention, probably due to their planktotrophic larvae and assumed widespread distribution (Cocks \& Fortey 2009), that they are not a component of the Palaeozoic Evolutionary Fauna (Sepkoski 1984; 1990) and perhaps because of perceived taxonomic difficulties.

Modern linguliform brachiopods have a planktotrophic larval stage which can remain in the plankton for several weeks before settling, leading to wider dispersion than articulate forms which have lecithotrophic larvae with short free-swimming duration (Hyman, 1959; Boucot 1975 and Williams 1973; 1976) indicate that rhynchonelliforms had limited ability to migrate across open oceans. There is strong evidence that many Palaeozoic lingulate brachiopods had planktotrophic larvae (Holmer, 1989; Popov \& Holmer 1994; Freeman \& Lundelius 1999). This implies that lingulate brachiopods should be more widely dispersed across the Iapetus and surrounding area than their articulate counterparts; indeed Harper \& Sandy (2001) note that the biogeographical patterns of lingulates can reflect those of planktonic organisms and Richardson (1997) notes that modern lingulates show no endemism. There are, however, few studies of the biogeography of Cambrian brachiopods, although Ushatinskaya (1996) provided an overview, identifying 'tropical' and 'natal' realms based on the proportion of lingulate to rhynchonelliform brachiopods. Popov \& Holmer (1994) established a series of lingulate brachiopod assemblages in the late Cambrian/early Ordovician and Bassett et al. (1999) discussed the diversification and extinction of lingulate brachiopods. Whilst not focussed on palaeogeography, Bassett et al. (2002) discussed the 
Cambrian to Tremadoc diversification of brachiopod faunas, both lingulate and articulate and Holmer \& Popov (1996) discussed the radiation, and classification, of the brachiopods in the lower Palaeozoic.

\author{
Aims of this study \\ This study has two principle aims; (1) to assess the utility of lingulate brachiopods in \\ palaeobiogeography, and (2) to assess whether the lingulate palaeobiogeographical data provides support \\ for long larval-residence times in lingulates. The distribution of lingulate brachiopods across the Iapetus \\ region in the lower Palaeozoic is analysed to assess whether they provide a biogeographic signal that \\ correlates with that provided by other faunal groups in documenting the opening and closing of the \\ Iapetus Ocean. Concordance of this type would predict that the faunas of Laurentia, Avalonia and Baltica \\ should become less similar through the Cambrian as the ocean opened, with maximum dispersal of \\ continents and consequently high levels of endemism in the early Ordovician. Avalonian and Baltican \\ faunas should become more similar throughout the Ordovician, becoming more or less cosmopolitan at \\ the end of the Ordovician as the continents collided with the closure of the Tornquist Sea; the faunas of \\ Laurentia and Baltica/Avalonia should also become increasingly similar, with reducing levels of \\ endemism, as the Iapetus Ocean closed and the distance between the continents decreased, before \\ collision in the Silurian when more or less cosmopolitan faunas should be established. Any discrepancy \\ between the lingulate biogeographic signal and that of other groups that implies earlier coalescence or \\ later divergence can be taken as support for the hypothesis that lingulate brachiopods larvae were \\ normally planktotrophic.
}

\title{
Methodology
}

The Treatise on Invertebrate Paleontology, part H (Kaesler, 1997; 2000 and Selden 2007) records the geographic and stratigraphic distributions of each brachiopod genus. From this data, a matrix of presence (1) and absence (0) of individual lingulate genera was compiled for each of the divisions of the Lower Palaeozoic used in the Treatise (three stages in the Cambrian, six in the Ordovician and four in the 
Silurian) on each palaeocontinent. Data from the Treatise for Avalonia has been supplemented by the lower Ordovician monograph of Sutton et al. (1999; 2000).

For the purposes of this study, Avalonia comprises England and Wales, Cape Breton, New Brunswick and Newfoundland, Laurentia consists of USA, Greenland, Scotland and Ireland and Baltica of Sweden, Poland, Novya Semlya, Russia (Ingria), Estonia and Norway, although the Norwegian faunas probably represent intra-Iapetus island faunas (Harper et al. 1996; 2009, Harper \& Sandy 2001). In other regions Siberia consists of Siberia, Russia (Altai) and Russia (undefined); Kazakhstan is comprised of Kazakhstan, Kirghizia and Uzbekistan; West Gondwana of Africa, France, Spain, Bohemia, Germany, Jordan and Libya, and East Gondwana consists of Australia, Antarctica and New Zealand.

There are some inherent limitations with the database used in this study. For example, a small number of genera, such as Lingulella, Lingulepis, Orbiculoidea and Schizotreta, have been excluded from the analysis as the Treatise records their exact geographic and stratigraphic distribution as uncertain; these are “wastebasket" genera into which often poorly preserved material has been recorded, and are in need of taxonomic revision. Also there are few modern publications describing lingulate faunas from the lower Palaeozoic of Avalonia; for example the Cambrian faunas from British Avalonia are currently being reviewed by one of us for the first time in 100 years. Additionally, very few lingulate taxa survived the late Ordovician faunal turnover associated with the Hirnantian glaciations; as a result the latter stages of the history of the Iapetus Ocean cannot be clearly elucidated from lingulates alone as a number of the indices could not be calculated for the Silurian.

A number of similarity coefficients/indices (see below) were calculated from the presence/absence database for global palaeocontinent pairs in each time-slice using the PAST statistics software (Hammer et al. 2001) and presented graphically to show changes over time. Data relating to seven palaeocontinental areas (Avalonia, Laurentia, Baltica, Siberia, Kazakhstan, West Gondwana and East Gondwana) has been used in calculating global similarity indices; there is insufficient data for the 
remaining areas (South Gondwana, North China and South China) to enable calculation of indices. The analysis for the Arenig and Llanvirn excludes East Gondwana as there is no data and for the whole of the Silurian only the Raup-Crick co-efficient can be calculated reliably due to scarcity of data, in particular for Avalonia. In this paper we consider only the results for those palaeocontinents impacting directly on the reconstruction of the history of the Iapetus region, namely Avalonia, Laurentia and Baltica.

To assess whether the patterns of lingulate brachiopod endemism across the three palaeocontinents reflect the expectations set out above, i.e. that endemism was at its maximum in the late Cambrian-early Ordovician, reducing steadily through the Ordovician, the Mean Endemism Index of Lees et al. (2002) has been calculated for each palaeocontinent pair, i.e. Laurentia/Baltica, Laurentia/Avalonia and Avalonia/Baltica using the formula ME $=0.5\left(\left(\mathrm{e}_{1} / \mathrm{t}_{1}\right)+\left(\mathrm{e}_{2} / \mathrm{t}_{2}\right)\right.$ where $\mathrm{e}_{1}$ and $\mathrm{e}_{2}$ are the numbers of lingulate taxa uniquely endemic to each palaeocontinent and $t_{1}$ and $t_{2}$ are the total number of lingulate taxa on each palaeocontinent; higher values for ME indicate higher levels of endemism and imply greater geographic separation. To further support this analysis the percentage of endemic lingulates, for all palaeocontinents combined, for each geological stage and the proportion of taxa on either one, two or all three palaeocontinents, has been calculated.

A further technique which has not been applied in this study is cladistic biogeography (see e.g. Lieberman \& Eldredge 1996). While this has been applied to Cambrian palaeogeography with some limited success, using trilobites (Lieberman 1997), the technique requires well resolved phylogenies. These are not currently available for lingulates, and indeed Fortey \& Cocks (2003) considered that there is insufficient knowledge of any invertebrate phylogenies for the approach to be viable.

\section{Selection of similarity coefficients/indices}

A large number of similarity coefficients or indices that derive from presence/absence data have been used in palaeontology and palaeogeography. Hammer \& Harper (2006) outline the characteristics of a number of indices for use in measuring the similarity of taxon compositions of two samples with 
presence/absence data. The Jaccard index (Jaccard 1912) ignores absences from both samples, assumes diversity differences are real and if one sample is much larger than the other will always yield a low value, whilst the Simpson index (Simpson 1949), which assumes differences are due to sampling, is insensitive to the size of the larger sample, effectively disregarding absences in the smaller sample; as a result only taxa present in the smaller sample contribute to the calculation and the results whilst being conservative, are less sensitive to the data. The Dice index (Dice 1945, Sorensen 1948) is similar to Jaccard but normalises to the average rather than the number of taxa in samples and is thus less sensitive to differences in sample sizes, giving more weight to joint occurrences. The Raup-Crick (Raup \& Crick 1979 ) is a probabilistic measure of faunal similarity based on the probability of the samples having taxa in common and uses a randomisation procedure based on bootstrapping. The Ochiai Coefficient of Closeness (Ochiai, 1957) is similar to the Jaccard and Dice indices in ignoring negative co-occurrences.

Hubalek (1982), evaluated 43 coefficients of similarity, and recommended the Jaccard, Dice, Kulczynski and Ochiai whilst Shi (1993) assessed 39 similarity coefficients using nine criteria for a "good index"; he concluded that the Jaccard coefficient was "the most suitable as a similarity measure", whilst also recommending the use of Simpson, Dice and Ochiai. However, Archer \& Maples (1987) and Maples \& Archer (1988) reviewed the utility of a number of indices under sub-optimal conditions, and concluded that the use of Dice, Simpson or Jaccard coefficients was inadvisable with sparse data or a high number of variables. Meanwhile Schmactenburg (2008) tested similarity indices against distances on proposed palaeogeographic reconstructions using modern and Cretaceous bivalves and concluded that the "RaupCrick similarity index is excellent for statistically testing palaeogeographic reconstructions with biogeographic data" and recommended the Raup-Crick index for testing palaeogeographic barriers, whilst also noting that where there were small differences in diversity the Raup-Crick index gave similar results to Simpson and where there were large diversity differences the results were more similar to Jaccard. Schmactenburg (2008) also reported that the Mean Endemism Index gave the worst correlation with distance between areas, whilst Lees et al. (2002) found better correlation between faunal similarity and 
distance using Mean Endemism than they did with Jaccard, although their data was at generic rather than specific level.

In view of the lack of consensus as to the most 'correct' or useful coefficient, we do not consider that selecting a single coefficient can easily be justified, and for this reason we have computed five (RaupCrick, Simpson, Jaccard, Dice and Ochiai).

\section{Results}

\section{Similarity Indices}

The calculated similarity indices for each palaeocontinent pair relevant to the history of the Iapetus (Laurentia/Baltica, Laurentia/Avalonia and Avalonia/Baltica) in each geological time slice for the Cambrian and Ordovician are set out in Figs 2-4. Comparable similarity indices have not been published for groups such as trilobites and articulate brachiopods; instead trends have been determined using more complex statistical analyses made viable by larger datasets (e.g. Cocks \& Fortey 1982; 1990; 2009 and Harper et al. 1996; 2009).

The results of our analyses vary depending upon which similarity coefficient is used and, although there is some support for predicted trends, it is not strong. Results for the Laurentia/Baltica palaeocontinentpair demonstrate the expected trend up to the end of the Ordovician, but neither Avalonia/Baltica or Avalonia/Laurentia show increases in similarity; indeed most indices for Avalonia/Baltica show decreasing similarity through the Ordovician. These trends are discussed in more detail below.

\section{Laurentia/Baltica (Fig. 2)}

All five indices show a similar pattern, with similarity decreasing to the end of the Cambrian and then steadily increasing through the Ordovician. The lowest levels of similarity are in all indices recorded in the late Cambrian, with values ranging from 0 (Raup-Crick) to 0.31 (Simpson) whilst the highest values 
recorded in the late Ordovician (Ashgill) range from 0.58 (Jaccard) to 0.96 (Raup-Crick). Sparsity of data in the Silurian renders calculation of indices other than Raup-Crick inadvisable; this latter index indicates a reduction in similarity rather than the expected increase, but small sample sizes urge caution in interpreting this result.

\section{[Insert Figure 2 here]}

\section{Laurentia /Avalonia (Fig. 3)}

The results for the Laurentia/Avalonia palaeocontinent pair show a general trend of decreasing similarity through time, although all but the Simpson index show a slight peak in the early Ordovician (Tremadoc). The Simpson index shows a general decrease from the Cambrian to the Arenig followed by an increase in the later Ordovician but with an anomalous result in the Ashgill which is related to the lack of taxa recorded on Avalonia.

\section{[insert Figure 3 here]}

\section{Avalonia/Baltica (Fig. 4)}

All indices show a trend of reducing similarity similar to that recorded in Avalonia/Laurentia from a peak in the Cambrian, steadily decreasing throughout the Ordovician, in contrast with the expectation based on palaeogeographic models. Whilst the Jaccard coefficient shows a decrease in similarity in the late Cambrian, this coefficient generally gives low values where one sample is much larger than the other, which is typically the case for the low diversity Avalonian faunas. The Simpson index yields high levels of similarity in the late Cambrian/early Ordovician; this is interpreted as an artefact relating to lack of sensitivity of this index at this time, as only data in the smaller sample (Avalonia) are used in the calculation. 


\section{[insert Figure 4 here]}

\section{Mean Endemism}

The mean endemism index (ME) for lingulate brachiopods calculated for each palaeocontinent pair is shown in Fig. 5 with the data set out in Appendix 1. If ME was to reflect the accepted history of the Iapetus Ocean it should increase during the Cambrian, peaking in the late Cambrian/early Ordovician when the palaeocontinents were at their maximum dispersal, before reducing through the Ordovician as the palaeocontinents converged.

The Laurentia/Baltica palaeocontinent pair reflects this expected pattern with the maximum endemism occurring in the late Cambrian and steadily reducing during the Ordovician, with a slight anomaly in the Caradoc. The maximum ME figure is 0.66 (Late Cambrian) whilst the minimum of 0.22 is recorded in the Llandeilo; the range calculated by Lees et al. (2002) for trilobites and brachiopods in the Ordovician and Silurian was 0.1 to 0.65 with a predominance of endemic taxa in the early to mid Ordovician, peaking for trilobites in the Arenig and for brachiopods in the Llanvirn.

As with similarity indices, the palaeocontinent pairs involving Avalonia do not give a clear signal, although the Avalonia/Baltica palaeocontinent pair does show increasing ME values from the lower Cambrian to the Arenig before reducing again steadily through the remaining Ordovician (a potentially anomalous peak in the Ashgill excepted). The peak ME values for Avalonia/Baltica occur later than Laurentia/Baltica; this is not predicted by the palaeogeographic model, but is in accordance with the trilobite and articulate brachiopod findings of Lees et al. (2002). The ME values for Avalonia/Laurentia show relatively little variation from the lower Cambrian through to the mid/late Ordovician and there is no clear signal in the data.

\section{[Insert Figure 5 here]}




\section{Other measures of endemism}

In addition to the Mean Endemism Index, the number of endemic lingulate taxa on each palaeocontinent (Fig. 6) and the percentage of endemic lingulate taxa across the Iapetus Ocean (Fig. 7) have been calculated and a graph produced showing the number of lingulate brachiopods distributed on one, two or all three palaeocontinents for each time period (Fig. 8).

The accepted history of the Iapetus Ocean would predict that the number of endemic taxa on each palaeocontinent and the percentage of endemic taxa across the Iapetus region should peak in the late Cambrian/early Ordovician at the time of maximum palaeocontinent dispersal, and reduce through the Ordovician to the cosmopolitan faunas of the Silurian. The number of taxa present on only one palaeocontinent should also peak at the same time, with an increasing proportion recorded on two, or all three, palaeocontinents through the lower Palaeozoic.

The percentage of endemic lingulate taxa (Fig. 6) reflects the history of the Iapetus region from the lower Cambrian, with the maximum percentage reached in the late Cambrian and remaining high until the Arenig when the percentage reduced significantly. Although there is an unexpected increase in the percentage of endemic taxa in the Silurian, this is based on very small numbers of lingulate brachiopods surviving the late Ordovician faunal turnover reported from a small number of sites; indeed there are no records in the Treatise of any lingulate brachiopods from the Silurian of Avalonia. While lingulates certainly existed in Avalonia during the Silurian (see e.g. Cocks \& Popov 2009), their absence from the treatise reflects a need for taxonomic revision.

\section{[insert Figure 6 here]}

The proportion of endemic lingulate taxa on each palaeocontinent in the Iapetus region in the Cambrian and Ordovician is summarised in Figure 7 which shows that, as expected, the proportion of endemic taxa on Baltica and Laurentia peak around the late Cambrian and early Ordovician, decreasing through the 
Ordovician. Data for Laurentia indicate that endemism peaked in the Cambrian and was already decreasing in the early Ordovician, earlier than anticipated from the development of the Iapetus. The results for Baltica are compatible with orthodox Iapetus history, with peak endemism from the late Cambrian to Arenig and a steady decrease through the Ordovician. Endemism in Avalonia, however, does not reflect the expected trend; instead, endemism increases throughout the Ordovician (no data is available for the Caradoc).

\section{[insert Figure 7 here]}

The number of endemic taxa across the three palaeocontinents around Iapetus rises rapidly through the Cambrian, peaking in the upper Cambrian to Arenig, gradually declining from then to the end of the Silurian (Fig 8). Whilst the number of taxa recorded reflects overall faunal diversity, the pattern recorded here also reflects the history of the Iapetus Ocean.

\section{[insert Figure 8 here]}

\section{Discussion}

\section{Faunal similarity}

Changes in faunal similarity of lingulate brachiopods for the Laurentia/Baltica palaeocontinent-pair show a clear signal which fits with the accepted history of the opening and closure of the Iapetus Ocean. Whilst articulate brachiopods and trilobites show maximum endemism in the early to mid Ordovician for this palaeocontinent pair, with faunas gradually becoming more similar due to migration from around mid-late Ordovician times, the trend towards increasingly similar faunas begins earlier for lingulate brachiopods. We interpret this as confirmatory evidence of a planktotrophic larval stage in Palaeozoic lingulate brachiopods, whose longer residence-time in the plankton can be expected to have enabled migration over wider oceanic distances than the lecithotrophic larval forms of articulate brachiopods and (presumably) trilobites. 
The results for the palaeocontinent-pairs involving Avalonia are more difficult to interpret. Avalonia was at higher latitudes than both Laurentia and Baltica in the Cambrian and lower Ordovician and the recorded lingulate faunas may reflect the typically lower diversity faunas found at higher latitudes. Laurentia was at low latitudes throughout the period, being shown as more or less equatorial in most reconstructions, whilst Baltica drifted northwards much earlier than Avalonia, although by the Caradoc they were both at mid latitude. It is also possible that ocean circulation patterns may have contributed to the distribution of taxa between Laurentia and Baltica at similar latitudes and provided a further barrier to northward migration of lingulates from Avalonia. Christiansen \& Stouge (1999) published a model of ocean circulation for the Arenig (Fig. 9) which shows Avalonia to the south of the temperate ocean current. To the east of it lay Baltica, with polar currents flowing westward from Avalonia, whilst Laurentia was located to the north of the subtropical ocean current in the Iapetus. In this model there appears to be a path for the distribution of faunas from Avalonia to Baltica in the early Ordovician via the mid latitude temperate current. However, the results of the endemism analysis presented here do not indicate high levels of faunal interchange between Avalonia and Baltica. Additionally, faunal interchange between Laurentia and Baltica, indicated in the endemism analysis and in analyses of trilobite and articulate brachiopod distributions, is difficult to envisage with this pattern of oceanic circulation. We hence consider that presently available faunal data does not support the model.

\section{[insert Figure 9 here]}

During the lower Ordovician, Baltica underwent anticlockwise rotation (Torsvik et al. 1993) meaning that different parts of the continent faced the Iapetus Ocean during this period. It is possible that different faunas might have existed on the western (Iapetus) and eastern (Tethys) margins of Baltica; as the database used in this study does not distinguish between western and eastern Baltica it is possible that this distinction may be a partial cause of the lack of clear signal in the data, although Cocks \& Fortey (2009) did not find any such faunal variation in Baltican trilobites and articulate brachiopods. 


\section{Endemism}

The results set out here indicate that maximum endemism for lingulate brachiopods occurred in the late Cambrian of Laurentia and lower Ordovician (Arenig) of Baltica although the Tremadoc data for Laurentia indicate an unusually low level of endemism which may reflect a lack of studies of Tremadoc faunas for this palaeocontinent and the low numbers of taxa recorded. Lees et al. (2002) noted that the highest levels of endemism for trilobites occurred in the Arenig and for the mainly articulate brachiopods in the Llanvirn; the earlier peak in endemism for lingulate brachiopods is interpreted as further evidence for their planktotrophic larval stage, and hence their potential for crossing wider oceans than other taxa which could only migrate when oceans had narrowed further.

The proportion of endemic lingulate taxa (Fig. 6) reflects, in broad terms, the width of the Iapetus Ocean and distances between the continents, peaking in the late Cambrian to Arenig at which time around three quarters of taxa were endemic to individual continents in the region. The majority of the remaining taxa were distributed on only two of the three palaeocontinents (Fig.8), typically Laurentia and Baltica, probably reflecting the relatively low diversity of higher latitude Avalonian faunas and consequent low numbers of taxa.

The early reduction in endemism in Laurentia (Fig. 7) is likely related to faunal interchange between Laurentia and other areas not associated with the Iapetus; for example, Laurentian faunas from the early Ordovician are similar to those recorded in Siberia and Gondwana. It is not clear why Avalonian lingulate faunas show high levels of endemism in the Ordovician though it may be related to Ocean circulation or the location of Avalonia to the south of Baltica in higher latitude, colder waters. It is also likely that Laurentian/Baltican faunas show lower levels of endemism as a result of their closer links with other, generally low latitude, palaeocontinents outside of the Iapetus region. 


\section{Conclusions}

Most authors have considered that lingulate brachiopods are of little utility in palaeogeographical reconstructions (e.g. Cocks \& Fortey 2009, Cocks 2011). Our analyses, however, indicate that where sufficiently diverse faunas of lingulates are recorded, they reflect palaeogeographic models derived from other sources, and hence provide a viable data source for reconstructions of continental configurations. Lingulate brachiopods clearly record the relative separation of Laurentia and Baltica during the lower Palaeozoic using a range of similarity indices; lack of clarity only occurs when the Avalonian microcontinent is considered, as the lingulate fauna here was both unusually endemic and low in diversity. The reasons for the anomalously high endemicity of Ordovician lingulates remain to be elucidated; they may include oceanic circulation patterns or latitudinal control, although why these should particularly affect lingulates remains unclear. Our data also provides consistent evidence of earlier increases in similarity during continental convergence than are observed in trilobites or articulate brachiopods, substantiating existing assumptions that Palaeozoic lingulates, like their living representatives, had long-lived planktotrophic larvae.

\section{References}

Alvaro, J.J., Elicki, O., Geyer, G., Rushton, A.W.A. \& Shergold, J.H. 2003 Palaeogeographical controls on the Cambrian trilobite immigration and evolutionary patterns reported in the western Gondwana margin Palaeogeography, Palaeoclimatology and Palaeoecology, 19, 5-35

Archer, A.W. \& Maples, C.G. 1987 Monte Carlo simulation of selected binomial similarity coefficients (II): effect of number of variables Palaios, 2, 609-617

Armstrong, H.A. \& Owen, A.W. 2002 Euconodont diversity changes in a cooling and closing Iapetus ocean Geological Society, London, Special Publications, 194, 85-98 
Bassett, M.G., Popov, L.E. \& Holmer, L.E. 1999 Organophosphatic brachiopods: patterns of diversification and extinction in the Early Palaeozoic Geobios, 32, 145-163

Bassett, M.G., Popov, L.E. \& Holmer, L.E. 2002 Brachiopods: Cambrian-Tremadoc precursors to Ordovician radiation events Geological Society, London, Special Publications, 194, 13-23

Berdan, J.M.1990 The Silurian and Early Devonian biogeography of ostracodes in North America Geological Society, London, Memoirs, 12, 223-231

Boucot, A.J. 1975 Evolution and extinction rate controls Elsevier, Amsterdam. 426pp.

Bruton, D.L. \& Harper, D.A.T. 1981 Brachiopods and trilobites of the early Ordovician serpentine Otta Conglomerate, south Central Norway Norsk Geologiosk Tisskrift, 61, 153-181

Carwood, P.A., McCausland, P.J.A. \& Dunning, G.R. 2001 Opening Iapetus: constraints from the Laurentian margin in Newfoundland Geological Society of America Bulletin, 113, 443-453

Christian, J.L. \& Stouge, S. 1999 Oceanic circulation as an element in palaeogeographical reconstructions: the Arenig (early Ordovician) as an example Terra nova, 11, 73-78

Clarkson, E. \& Upton, B. 2010 Death of an Ocean. A geological borders ballad. 210pp, Dunedin Academic Press

Cocks, L.R.M. 2000 The early Palaeozoic geography of Europe Journal of the Geological Society, London, 157, 1-10

Cocks, L.R.M. 2011 There's no place like home: Cambrian to Devonian brachiopods critically useful for analysing palaeogeography Memoirs of the Association of Australian Palaeontologists, 41, 135-148 
Cocks, L.R.M. \& Fortey, R.A. 1982 Faunal evidence for oceanic separations in the Palaeozoic of Britain J. Geol. Soc. London, 139, 465-478

Cocks, L.R.M. \& Fortey, R.A. 1990 Biogeography of Ordovician and Silurian faunas Geological Society, London, Memoirs, 12, 97-104

Cocks, L.R.M. \& Fortey, R.A. 2009 Avalonia: a long-lived terrane in the Lower Palaeozoic? From:

Bassett, M.G. (ed.) 2009 Early Palaeozoic peri-Gondwanan terranes: new insights from tectonics and biogeography, Geological Society, London, Special Publications, 325, 141-155

Cocks, L.R.M. \& McKerrow, W.S. 1973 Brachiopod distributions and faunal provinces in the Silurian and Lower Devonian Special Papers in Palaeontology 12, 291-304

Cocks, L.R.M. \& Popov, L.E. 2009 Generic homes for British Silurian Linguloid brachiopods Palaeontology, 52, 349-367

Cocks, L.R.M. \& Torsvik, T.H. 2002 Earth Geography from 500-400 Million years ago: a faunal and palaeomagnetic perspective J. Geol. Soc. London, 159, 631-644

\author{
Conway Morris, S. \& Rushton, A.W.A. 1988 Precambrian to Tremadoc biotas in the Caledonides. In: \\ Harris, A.L. and Fettes, D.J. (Eds.) The Caledonian-Appalachian Orogen Geological Society Special \\ Publications No. 38, 93-110
}

Dice, L.R. 1945 Measures of the amount of ecological association between species Ecology, 26, 297-302

Fortey, R.A. \& Cocks, L.R.M 1992 The Early Palaeozoic of the North Atlantic region as a test case for the use of fossils in continental reconstruction Tectonophysics, 206, 147-158 
Fortey, R.A. \& Cocks, L.R.M 2003 Palaeontological evidence bearing on global Ordovician - Silurian continental reconstructions Earth Science Reviews, 61, 245-307

Fortey, R.A. \& Mellish, C.J.T. 1992 Are some fossils better than others for inferring palaeogeography Terra Nova, 4, 210-216

Freeman, G. \& Lundelius, J.W. 1999 Changes in the timing of mantle formation and larval life history traits in linguliform and Craniiform Lethaia, 32, 197-217

Hammer, O. \& Harper, D.A.T 2006 Palaeontological data analysis Blackwell publishing, 1-351

Hammer, O., Harper, D.A.T. \& Ryan, P.D. 2001 PAST: Palaeontological statistics software package for education and data analysis Palaeontologica Electronica, 4, $9 \mathrm{pp}$.

Hansen, J. \& Holmer, L.E. 2010 Diversity fluctuations and biogeography of Ordovician brachiopod faunas in northeastern Spitsbergen Bulletin of Geosciences, 85, 497-504

Harper, D.A.T., MacNiocaill, C. \& Williams, S.H. 1996 The palaeogeography of early Ordovician Iapetus terranes: an integration of faunal and palaeomagnetic constraints Palaeogeography, Palaeoclimatology and Palaeoecology, 121, 297-312

Harper, D.A.T., Owen, A.W. \& Bruton, D.L. 2009 Ordovician life around the Celtic fringes:

diversifications, extinctions and migrations of brachiopod and trilobite faunas at middle latitudes From: Bassett, M.G. (ed.) 2009 Early Palaeozoic peri-Gondwanan terranes: new insights from tectonics and biogeography, Geological Society, London, Special Publications, 325, 157-170 
Harper, D.A.T. \&Sandy, M.R. 2001 Palaeozoic Brachiopod biogeography In S. J. Carlson \& M. R.

Sandy, eds., Brachiopods Ancient and Modern. A Tribute to G. Arthur Cooper, vol. 7. The

Paleontological Society. Pittsburgh. p. 207-222

Havlicek, V. 1976 Evolution of Ordovician brachiopod communities in the Mediterranean Province, 349-

358 In Bassett, M.G. Aspects of The Ordovician System, Proceedings of a Palaeontological Association

Symposium, Birmingham University of Wales Press and National Museum of Wales, Cardiff 696pp

Havlícek, V., Vanek, J., \& Fatka, O. 1994. Perunica microcontinent in the Ordovician (its position within the Mediterranean Province, series division, benthic and pelagic associations) Sbornik geologickych ved, Geologie. 46, 23-56

Holmer, L.E. 1989 Middle Ordovician phosphatic inarticulate brachiopods from Vastergotland and Dalarna, Sweden Fossils \& Strata, 26, 1-172

Holmer, L.E. \& Popov, L.E. 1996 Early Palaeozoic radiation and classification of organo-phosphatic brachiopods In: Copper, P. and Jin, J. Brachiopods Proceedings of the third international brachiopod congress

Hubalek, Z. 1982 Coefficients of association and similarity based on binary (presence-absence) data: an evaluation Biological reviews, 57, 669-689

Hughes, N.C. \& Rushton, A.W.A. 1990 Computer aided restoration of a late Cambrian ceratopygid trilobite from Wales and its phylogenetic implications Palaeontology, 33, 429-446

Hurst, J.M 1979 Evolution, succession and replacement in the type Caradoc (Upper Ordovician) benthic faunas of England Palaeogeography, Palaeoclimatology, Palaeoecology, 27, 189-246

Hyman, L.H. 1959 The Invertebrates 5: Smaller Coelomate Groups, 516-609 McGraw-Hill, New York 
Jaanusson, V. 1973 Aspects of the carbonate sedimentation in the Ordovician of Baltoscandia Lethaia, 6, 11-34

Jaccard, P. 1912 The distribution of the flora of the alpine zone New Phytologist, 11, 37-50

Kaesler, R.L. (Ed.) 1997 Treatise on Invertebrate Palaeontology, Part H (Brachiopoda, Revised), Volume 1: Introduction Geological Society of America and University Of Kansas Press, xx+359p., 417 fig, 40 tables

Kaesler, R.L. (Ed.) 2000 Treatise on Invertebrate Palaeontology, Part H (Brachiopoda, Revised), Volumes 2 and 3: Linguliformea, Craniiformea and Rhynchonelliformea (part) Geological Society of America and University Of Kansas Press, xxx+919p.,616 fig, 17 tables

Landing, E. 2005 Early Palaeozoic Avalon-Gondwana unity: an obituary - response to "Palaeontological evidence bearing on global Ordovician-Silurian continental reconstructions" by R.A. Fortey and L.R.M. Cocks Earth Science Reviews, 69, 169-175

Lees, D.C., Fortey, R.A. \& Cocks, L.R.M. 2002 Quantifying paleogeography using biogeography: a test case for the Ordovician and Silurian of Avalonia based on brachiopods and trilobites Paleobiology, 28, $343-363$

Lieberman, B.S. 1997 Early Cambrian paleogeography and tectonic history: A biogeographic approach Geology, 25, 1039-1042

Lieberman, B.S. \& Eldredge, N. 1996 Trilobite biogeography in the Middle Devonian: geological processes and analytical methods Paleobiology, 22, 66-79 
Linneman, U., Herbosch, A., Liegeois, J-P., Pin, C., Gartner, A. \& Hofmann, M. 2012 The Cambrian to

Devonian odyssey of the Brabant-Massif within Avalonia: A review of new zircon ages, geochemistry, Sm-Nd isotopes, stratigraphy and palaeogeography Earth Science Reviews, 112, 126-154

MacNiocaill, C., van der Pluijm, B.A. \& Van der Voo, R. 1997 Ordovician palaeogeography and the evolution of the Iapetus Ocean Geology, 25, 159-162

Maples, C.G. \& Archer, A.W. 1988 Monte Carlo simulation of selected binomial similarity coefficients (II): effect of sparse data Palaios, 3, 95-103

McKerrow, W.S. \& Cocks, L.R.M. 1986 Oceans, island arcs and olistostromes: the use of fossils in distinguishing sutures, terranes and environments around the Iapetus ocean J. Geol. Soc. London, 143, $185-191$

Neuman, R.B. 1984 Geology and paleobiology of islands in the Ordovician Iapetus Ocean Bulletin of the Geological Society of America, 95, 1188-2011

Neuman, R.B. \& Harper, D.A.T. 1992 Paleogeographic significance of Arenig-Llanvirn Toquima-Table Head and Celtic brachiopod assemblages In: D.B. Webby and J.R. Laurie (Editors) Global Perspectives in Ordovician Geology, Balkema, Rotterdam, pp. 241-254

Ochiai, A. 1957 Zoogeographical studies on the soleoid fishes found in Japan and neighbouring regions II Bulletin of Japanese Social Sciences, 22, 526-530

Owens, R.M. \& Servais, T. 2007 The Ordovician of the Condroz Ridge, Belgium: trilobites from the south-eastern margin of Avalonia Palaeogeography, Palaeoclimatology and Palaeoecology, 245, 272294 
Pisarevsky, S.A., Murphy, J.B., Cawood, P.A. \& Collins, S.A. 2008 Late Neoproterozoic and Early Cambrian palaeogeography: models and problems Geological Society of London, Special Publications, 294, 9-31

Popov, L. \& Holmer, L.E. 1994 Cambrian-Ordovician lingulate brachiopods from Scandinavia, Kazakhstan and South Ural Mountains Fossils \& Strata, 35, 1-156

Raup, D. \& Crick, R.E. 1979 Measurement of faunal similarity in paleontology Journal of Paleontology, 53, 1213-27

Richardson, J.E. 1997 Ecology of articulated brachiopods. In: Kaesler RL (ed.) Treatise on invertebrate paleontology. Part H, Brachiopoda, vol. 1. Geological Society of America and the University of Kansas Press, Boulder, Colorado and Lawrence, Kansas, pp 441-462

Samuelson, J. \& Verniers, J., 2000. Ordovician chitinozoan biozonation of the Brabant Massif, Belgium. Review of Palaeobotany and Palynology, 113, 105-129

Selden, P.A. (Ed.) 2007 Treatise on Invertebrate Palaeontology, Part H (Brachiopoda, Revised), Volume 6 Geological Society of America and University Of Kansas Press, $l+906 p ., 461$ fig, 38 tables

Schmachtenburg, W.F. 2008 Resolution and limitations of faunal similarity indices of biogeographic data for testing predicted palaeogeographic reconstructions and estimating intercontinental distances: A test case of modern and Cretaceous bivalves Palaeogeography, Palaeoclimatology and Palaeoecology, 265, 255-261

Shi, G.R. 1993 Multivariate data analysis in palaeoecology and palaeobiogeography - a review Palaeogeography, Palaeoclimatology and Palaeoecology, 105, 199-234

Simpson, E.H. 1949 Measurement of diversity Nature, 163, 688 
Sorensen, T. 1948 A method of establishing groups of equal amplitude in plant sociology based on similarity of species content Det Kongelige Danske Videnskab. Selskab, Biologiske Skrifter, 5, 1-34

Sutton, M.D., Bassett, M.G. \& Cherns, L. 1999 Lingulate brachiopods from the Lower Ordovician of the Anglo-Welsh basin: Part 1 Monograph of the Palaeontographical Society, 153, 1-60, pl. 1-8

Sutton, M.D., Bassett, M.G. \& Cherns, L. 2000a Lingulate brachiopods from the Lower Ordovician of the Anglo-Welsh basin: Part 2 Monograph of the Palaeontographical Society, 153, 61-114, pl. 9-23

Topper, T.P., Skovsted, C.B., Brock, G.A. \& Paterson, J.R. 2011 The oldest bivalved arthropods from the early Cambrian of East Gondwana: systematics, biostratigraphy and biogeography Gondwana Research, $19,310-236$

Torsvik, T.H. \& Rehnstrom, E.F. 2003 The Tornquist Sea and Baltica - Avalonia docking Tectonophysics, 362, 67-82

Torsvik, T.H., Smethurst, M.A., Meert, J.G., Van der Voo, R., McKerrow, W.S., Brasier, M.D., Sturt, B.A. \& Walderhaug, H.J. 1996 Continental break up and collision in the Neoproterozoic and Palaeozoic - A tale of Baltica and Laurentia Earth-Science Reviews, 40, 229-258

Torsvik, T.H. \& Trench, A. 1991 The Ordovician history of the Iapetus Ocean in Britain: new palaeomagnetic constraints Journal of the Geological Society, London, 148, 423-425

Torsvik, T.H., Trench, A., Svensson, I. \& Walderhaug, H.J. 1993 Silurian palaeomagnetic results from southern Britain: palaeogeographic significance and major revision of the Apparent Polar Wander Path for Eastern Avalonia Geophysical Journal International, 113, 651-668

Tychsen, A \& Harper, D.A.T. 2004 Ordovician-Silurian distribution of Orthida (Palaeozoic Brachiopoda) in the greater Iapetus region Palaeontologica Electronica, 7 (3), 15pp 
Ushatinskaya, G.T. 1996. Brachiopod paleozoogeography through the Cambrian. In: Copper, P. and Jin Jisuo, Brachiopods, pp. 275-280. Proceedings of the third international brachiopod congress

Verniers, J., Pharaoh, T., Andre, L., Debacker, T.N., De Vos, W., Evereaerts, M., Herbosch, A., Samuelsson, J., Sintubin, M. \& Vecoli, M. 2002 The Cambrian to mid Devonian basin development and deformation history of Eastern Avalonia, east of the midlands Microcraton: new data and a review Geological Society, Special Publications, 201, 47-93

Verniers, J., Vandenbroucke, T.R.A. \& Nielsen, A.T. 2005. Chitinozoan biozonation at the OrdovicianSilurian transition in Dob's Lin (Scotland, U.K.) and Lonstorp (Scania, Sweden). In: Eriksson, M.E., Calner, M. (Eds.), The Dynamic Silurian Earth. Field Meeting of the Subcommission on Silurian Stratigraphy 2005, Gotland, Rapporter och meddelanden-Sveriges Geologiska Undersokning vol. 121, pp. 96-97.

Whittington, H.B. \& Hughes, C.P 1972 Ordovician geography and faunal provinces deduced from trilobite distribution Philosophical Transactions of the Royal Society of London, Series B 263, 235-278

Williams, A. 1969 Ordovician faunal provinces with reference to brachiopod distribution. In: Wood, A. (Ed.) The Precambrian and Lower Palaeozoic rocks of Wales. University of Wales Press, Cardiff, pp. $117-154$

Williams, A. 1973 Distribution of brachiopod assemblages in relation to Ordovician palaeogeography in Hughes, N.F. Ed. Organisms and Continents through time: Palaeontological Association, Special Papers in Palaeontology, 12, p. 241-269

Williams, A. 1976 Plate tectonics and biofacies evolution as factors in Ordovician correlation, In: Bassett, M.G. (Ed) The Ordovician system, Proceedings of a Palaeontological Association Symposium, University of Wales Press and National Museum of Wales, Cardiff, 29-66 
2

Williams, M., Siveter, D.J., Popov, L.E., \& Vannier, J.M.C. 2007 Biogeography and affinities of the bradoriid arthropods: Cosmopolitan microbenthos of the Cambrian seas Palaeogeography,

Palaeoclimatology and Palaeoecology, 248, 202-232

Wilson, T.J. 1966 Did the Atlantic close and then re-open? Nature, 211, 676-681

Ziegler, A.M., Cocks, L.R.M. \& Bambach, R.K. 1968 The composition and structure of Lower Silurian marine communities Lethaia, 1, 1-27 


\section{Figure Captions}

Figure 1: summary of Ordovician stratigraphic terminology used herein (based on United Kingdom) against the modern global standard (adapted from

http://ordovician.stratigraphy.org/uploads/OrdChartHigh.jpg)

Figure 2: Similarity Indices for the Laurentia/Baltica palaeocontinent pair through the Cambrian and Ordovician

Figure 3: Similarity Indices for the Laurentia/Avalonia palaeocontinent pair through the Cambrian and Ordovician

Figure 4: Similarity Indices for the Avalonia/Baltica palaeocontinent pair through the Cambrian and Ordovician

Figure 5: Mean Endemism Index for each palaeocontinent pair through the Cambrian and Ordovician

Figure 6: Percentage of endemic lingulate taxa around the Iapetus Ocean through the lower Palaeozoic

Figure 7 Proportion of endemic taxa on each palaeocontinent in the Iapetus region

Figure 8: Distribution of lingulate taxa across the three palaeocontinents around the Iapetus Ocean (showing the number of taxa recorded on one, two or three of the palaeocontinents under consideration)

Figure 9 Ocean circulation for the Arenig, showing brachiopod provinces (From Christiansen and Stouge 1999) 


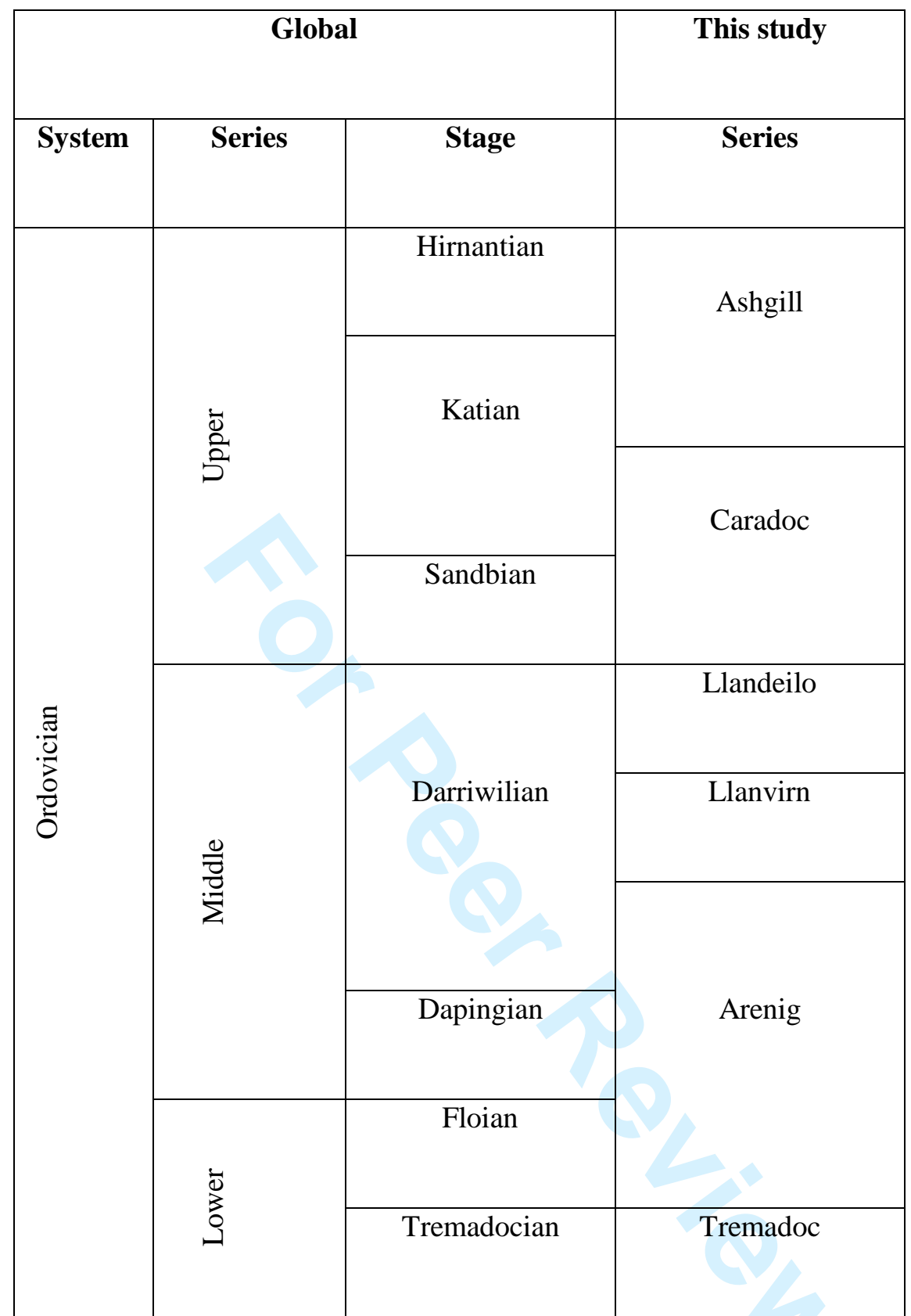




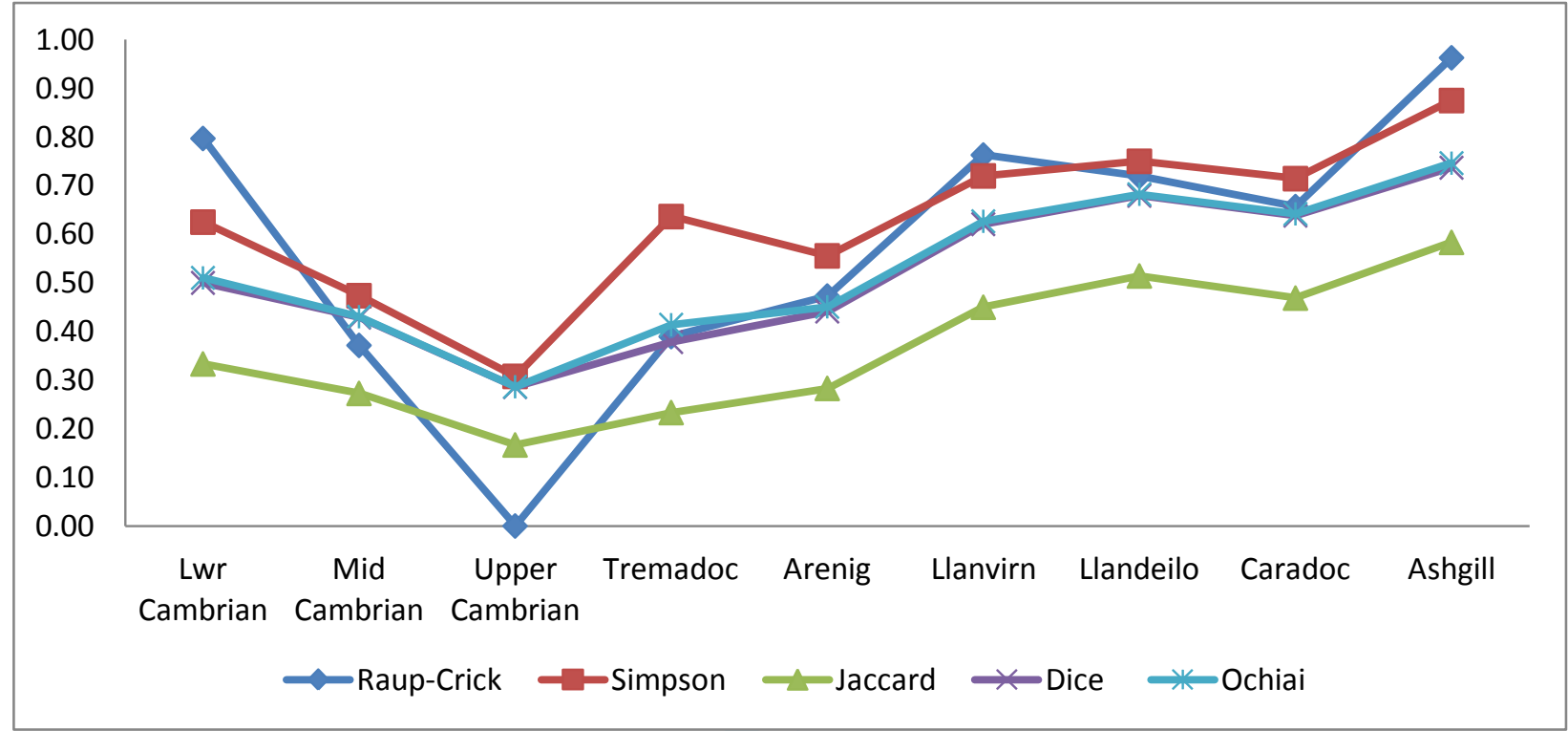




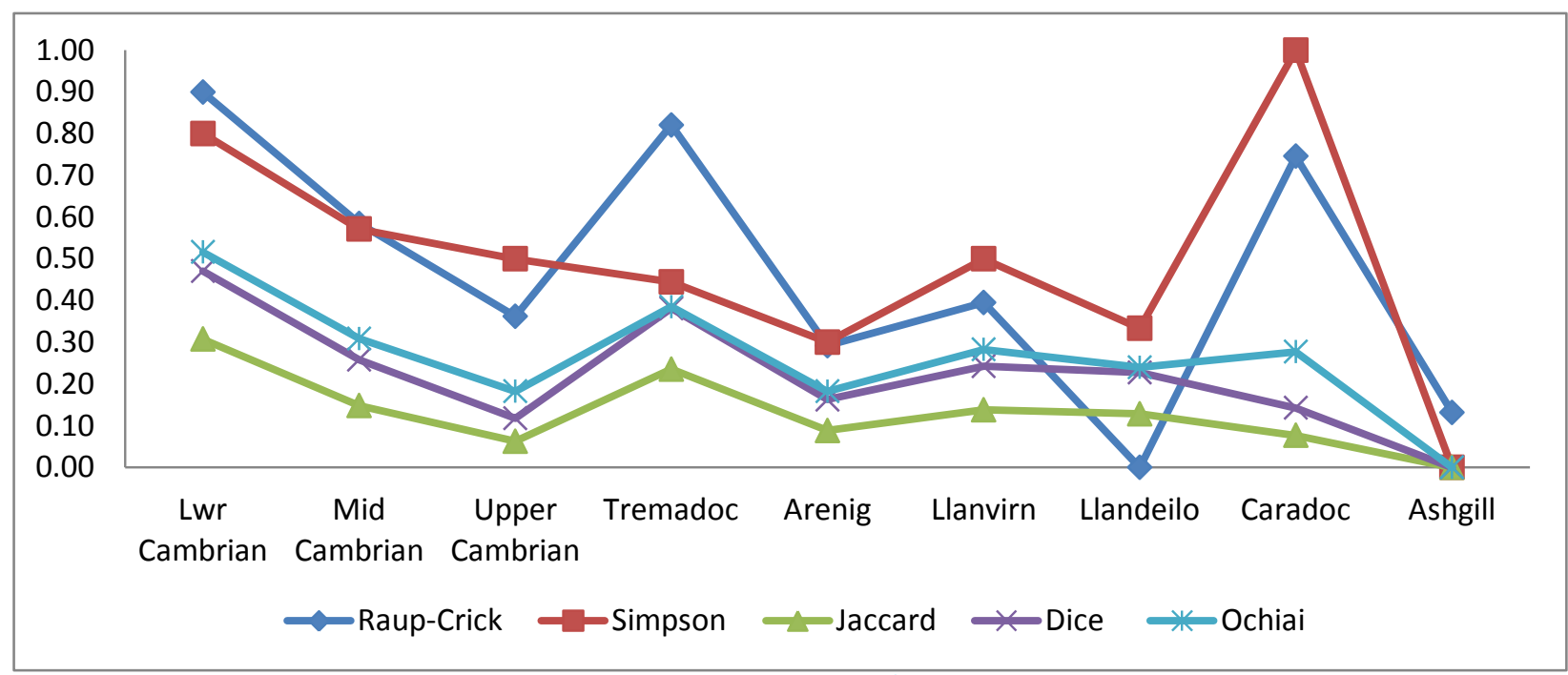




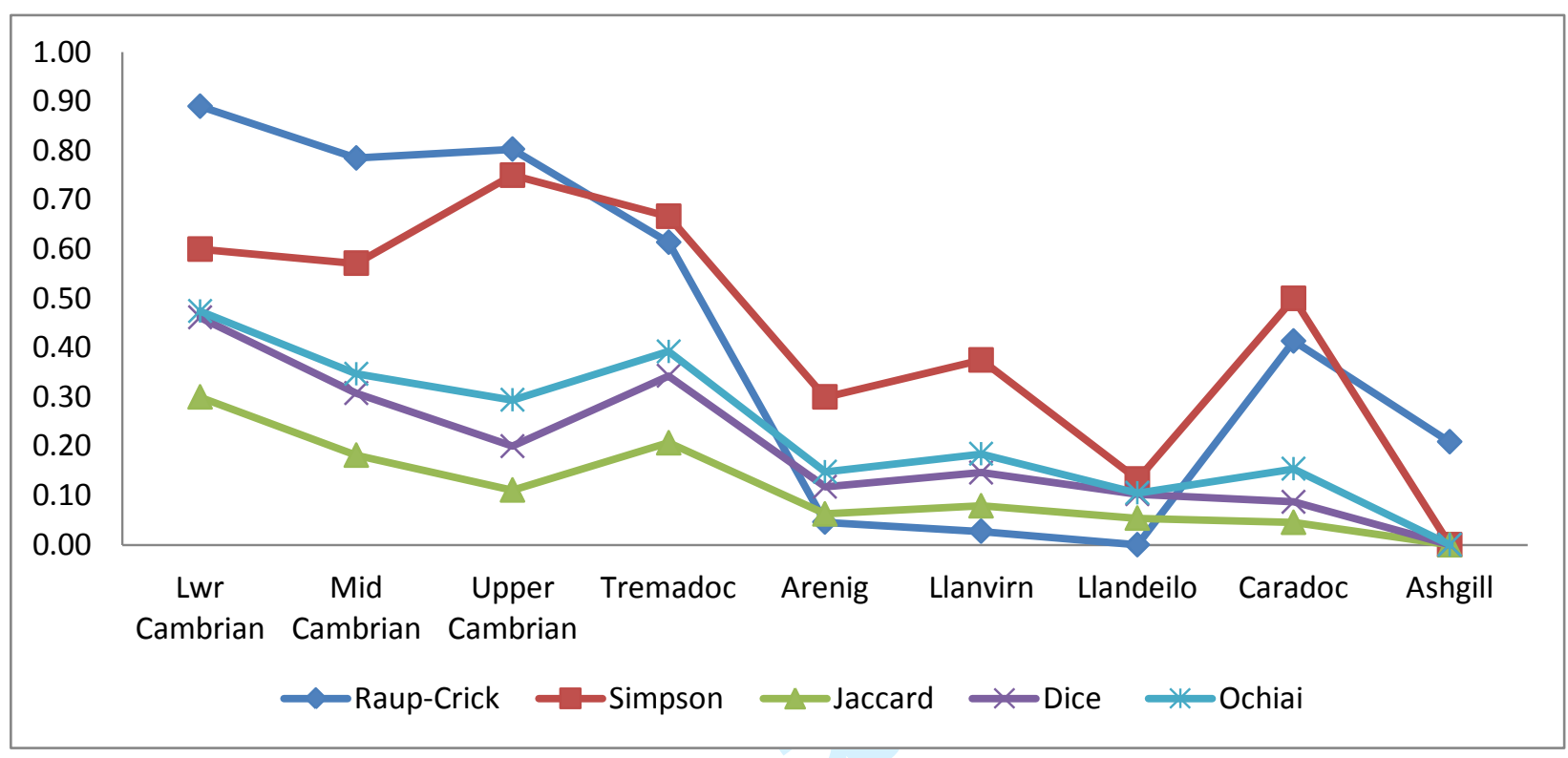




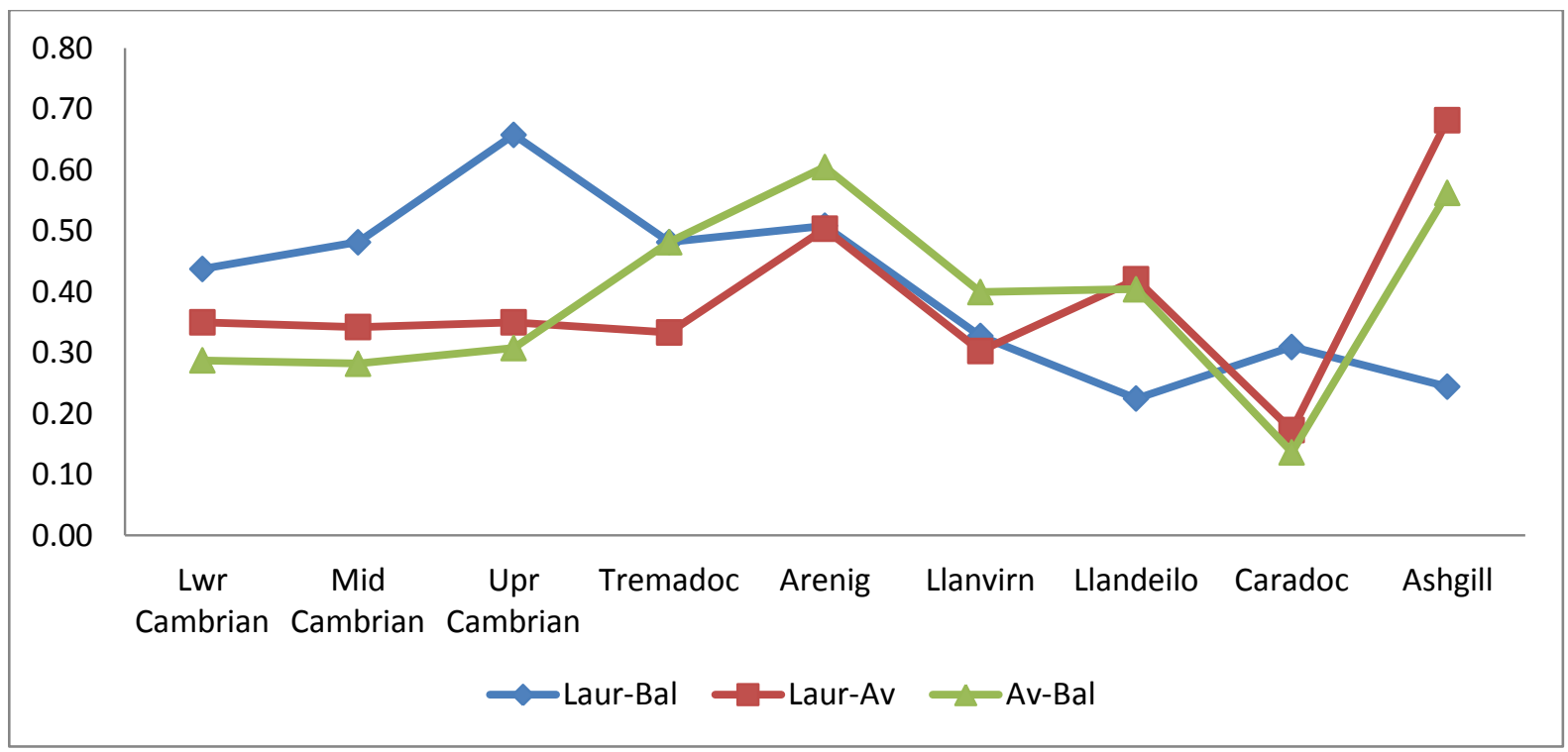




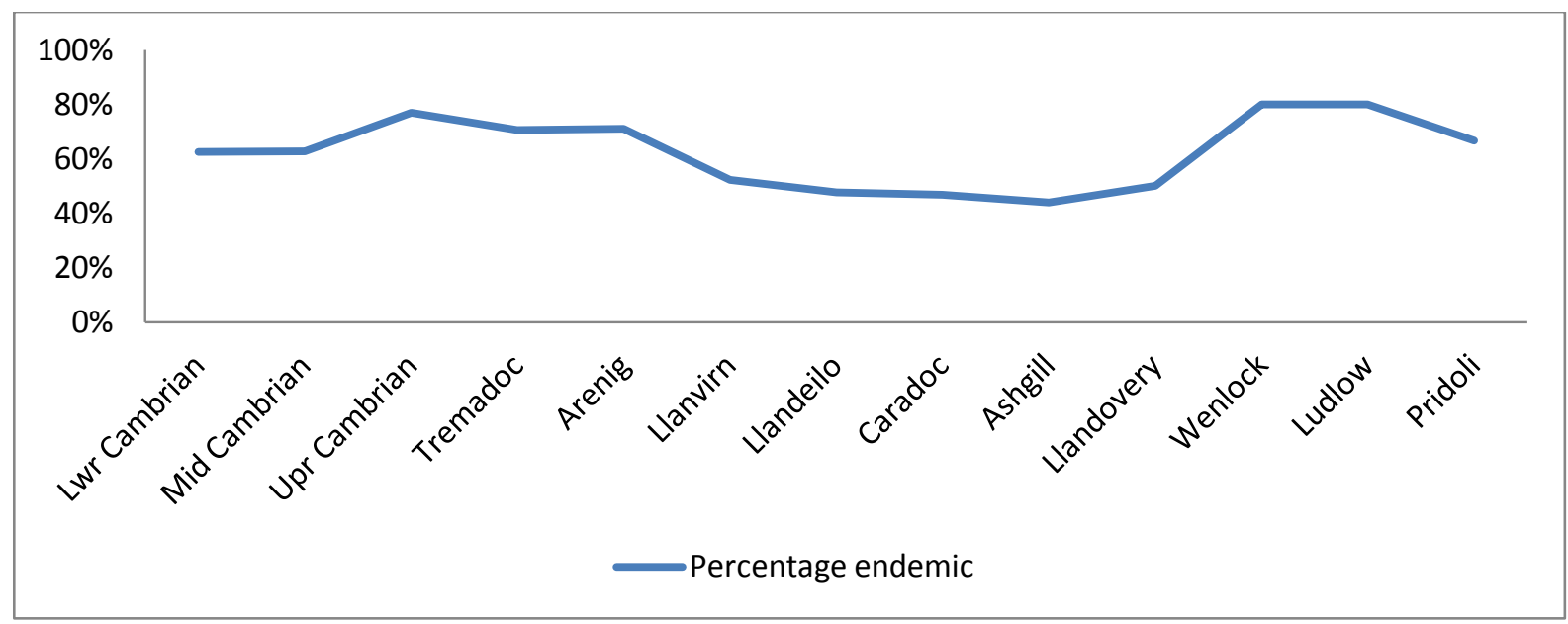




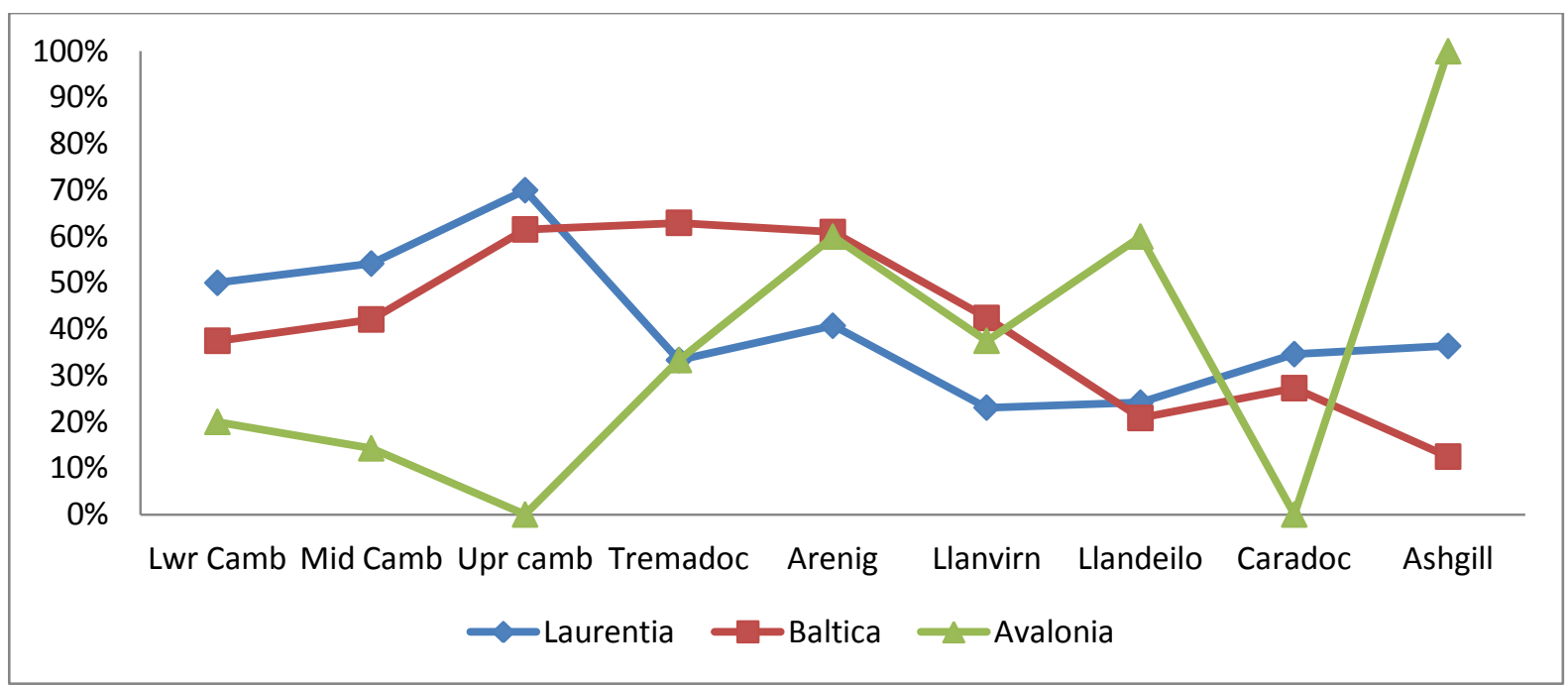




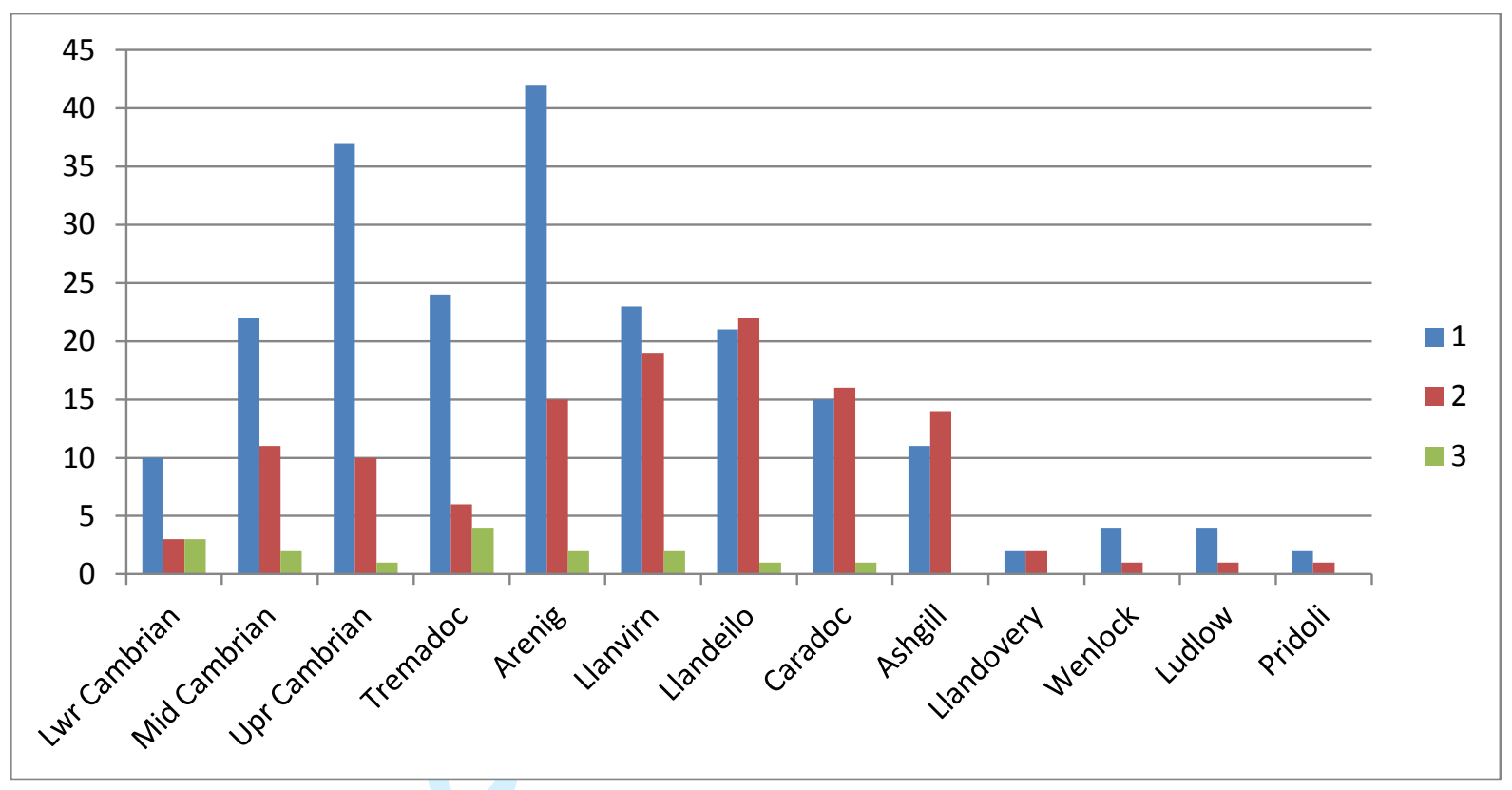




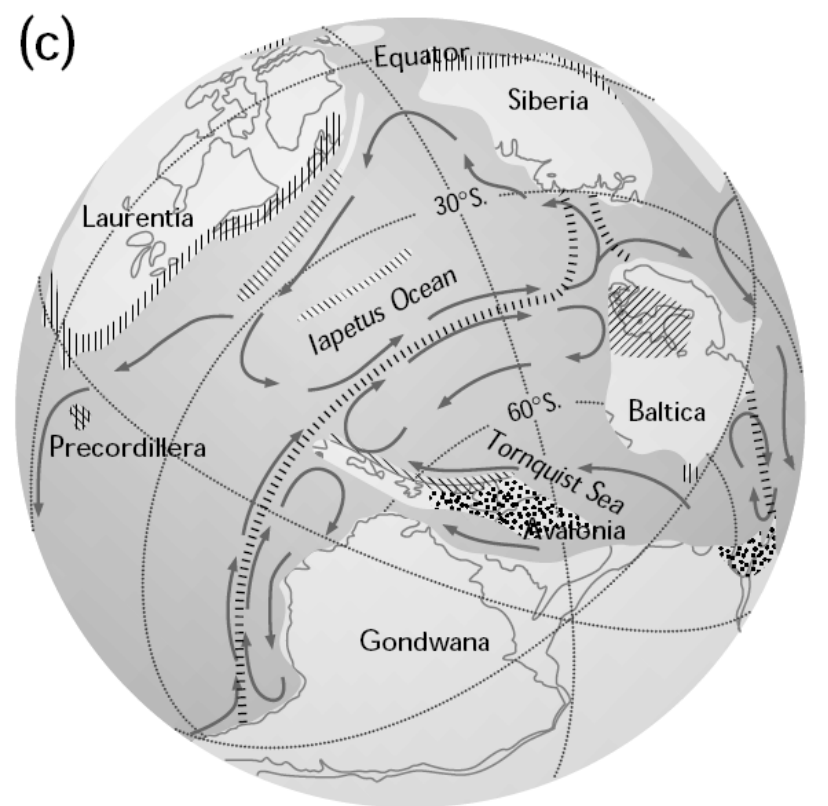

|m

$\mathbb{1}$ Celtic Province

VII Baltic Province 屡咚 Anglo-French Province 